\title{
Does grassland introduction into cropping cycles affect carbon dynamics through changes of allocation of soil organic matter within aggregate fractions?
}

\author{
M. Panettieri ${ }^{\text {a,* }}$, C. Rumpel ${ }^{\text {b }}$, M.-F. Dignac ${ }^{\text {a }}$, A. Chabbi ${ }^{\text {a,c }}$ \\ a UMR ECOSYS, INRA, AgroParisTech, Université Paris-Saclay, 78850, Thiverval-Grignon, France \\ b UMR IEES, CNRS, UPMC, UPEC, IRD, INRA, 78850, Thiverval-Grignon, France \\ c UR P3F, INRA, 86600, Lusignan, France
}

\section{H I G H L I G H T S}

- Changes on soil organic matter dynamics under different land uses are still poor understood.

- Lignin biomarkers and isotopic signature were measured in water stable aggregates.

- Lignin was preserved and carbon was stored in larger aggregates under grassland.

- Litter quality and land use reduced carbon turnover in fine fractions of ley grassland.

- Grassland footprint is still relevant after three years of continuous cropping.

\section{A R T I C L E I N F O}

\section{Article history:}

Received 3 June 2016

Received in revised form 10 October 2016

Accepted 10 October 2016

Available online 24 October 2016

Editor: D. Barcelo

\section{Keywords:}

Ley grassland

Lignin

Agroecosystems

Land use

Bare soil

Stable isotopes

\section{G R A P H I C A L A B S T R A C T}

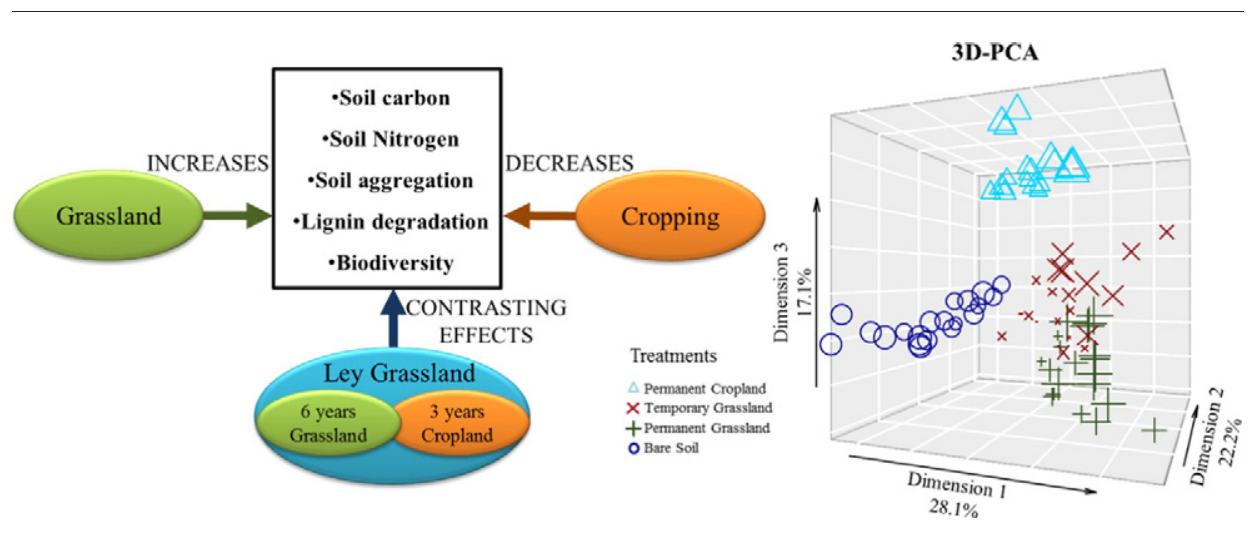

\begin{abstract}
A B S T R A C T
Implementation of ley grassland into crop rotation could have positive influence in soil ecosystem services such as $\mathrm{C}$ storage. The periodical changes of land-use plus the in situ labelling given by the introduction of maize crops under ley grassland induce differences in soil organic matter (SOM) that could be traced either by stable isotopes or by the characterization of plant biomarkers such as lignin derived phenols. Evaluation of SOM dynamics is often limited by the complexity of soil matrix. To override these limitations, a hierarchical approach to decompose the soil mosaic into aggregates has been proposed in this study. Soil and plant samples were collected from a long-term experimental area in Lusignan (western France). Soils from four different treatments (bare fallow, permanent maize, permanent grassland, and ley grassland based on 6 years of grassland followed by 3 years of maize) were sampled, fractionated into water stable aggregates, and finally analysed for carbon, nitrogen, and lignin contents, as well as for ${ }^{13} \mathrm{C}$ isotopic signature.

Soils under ley and permanent grassland stored higher amount of SOM in larger aggregates and preserved more efficiently the lignin stocks than the corresponding samples under permanent maize. Contemporary, finer fraction of ley grassland showed higher mean residence time of organic carbon, probably due to a legacy effect of the previous years under grassland. Even if maize derived SOM was identified, the grassland footprint was still dominating the ley grassland soils, as described by the principal component analysis. Strong correlation between these results and the quality and stoichiometry of the vegetal litter returned to soil were found, evidencing the
\end{abstract}

\footnotetext{
* Corresponding author.

E-mail address: marco.panettieri@grignon.inra.fr (M. Panettieri).
} 
needs for a comprehensive evaluation at a molecular level of all the parameters modified by land-use changes, including tillage, to understand the potential for carbon storage of different agroecosystems.

(C) 2016 Elsevier B.V. All rights reserved.

\section{Introduction}

Achieving a sustainable equilibrium among agricultural practices and environment is the main goal for agronomic research nowadays (Smith et al., 2015a, b; Keesstra et al., 2016) Land management should tend to a sustainable agriculture to guarantee or improve crop yields and soil quality, while limiting greenhouse gases emissions (Lal, 2000; IPCC, 2013). Perennial systems, such as grassland, or alternation of grassland and cropland have been indicated as more efficient than permanent cropping systems in terms of $\mathrm{C}_{\text {org }}$ sequestration and increasing biodiversity and nutrient availability of the agroecosystem (Lemaire et al., 2011; Gelfand et al., 2013; Lemaire et al., 2015; Parras-Alcántara et al., 2015; Rumpel et al., 2015). Therefore, temporary or ley grassland should be considered not only in terms of fodder production for livestock, but also as a landscape area for realizing some essential ecosystem services, such as absorbing negative environmental impacts resulting from intensive agriculture (Lemaire et al., 2015). For exemple, nitrate leaching was greatly reduced after the introduction of ley grassland into a cropping cycle (Kunrath et al., 2015).

Soil organic matter (SOM) plays a key role for agroecosystems, given that increasing carbon stocks concomitantly improves soil structure, fertility, and crop yields (Six et al., 1999; Lal, 2002). The storage of organic compounds in soil is mainly achieved by promoting the retention of the litter proceeding from previous crops and/or the incorporation of amendments. However, the mechanisms that underlie the incorporation of $C_{\text {org }}$ from residual plant litter into the mineral soil remain widely unknown, since they are widely variable depending on edaphoclimatic characteristics and land-use (Kögel-Knabner and Ziegler, 1993; Gleixner et al., 2002; Franzluebbers, 2004; Panettieri et al., 2015). Furthermore, the complexity of soil samples has always represented a major barrier for molecular-scale analyses of SOM (Derenne and Nguyen Tu, 2014).

In recent studies, the combination of a hierarchic approach provided by soil fractionation and successive chemical characterization of SOM pools has been used as a way to identify different behaviours of SOM at a molecular level (Ludwig et al., 2015; Panettieri et al., 2015). In addition, stable isotope analyses were extensively used to measure the turnover of SOM under different conditions, especially for land-use changes and for conversion from C3 to C4 vegetation (Balesdent et al., 1987; Balesdent and Mariotti, 1996; Dignac et al., 2005). Larger aggregate fraction was identified as the most reactive to changes in land-use, and aggregate disruption induced by tillage has been correlated to carbon losses, worsening of soil physical properties and soil quality (Six et al., 2000a; Bronick and Lal, 2005; Panettieri et al., 2013; Six and Paustian, 2014). However, other authors found more pronounced changes in chemical composition of SOM in smaller size fractions when grassland was changed to arable land (Leifeld and Kögel-Knabner, 2005).

While disaggregating forces are often exogenous or related to changes in land-use, aggregation is mainly led by intrinsic factors of the soil-plant-water system, as for example root activity (Rasse et al., 2005 ) and the composition of organic inputs added to soil (Hu et al., 2016). Green litter or mucilage demonstrated to greatly increase aggregation at short term, whereas more stabilized OM sources as compost or humified substances have an impact of lower magnitude but more prolonged in time (Abiven et al., 2009).

A deeper follow up of OM accrual after introduction of ley grassland into cropping systems has been carried out using specific plant biomarkers and in situ labelling (Armas-Herrera et al., 2016). Among biomarkers, lignin derived compounds are specifically synthetized by plants and largely stored in soil via selective interactions within some of the compartments of soil matrix (Clemente and Simpson, 2013).

Lignins represent approximately $20 \%$ of litter input into soils (Thevenot et al., 2010) and is characterized by slow decomposition rates, thereby being a major controlling compound of litter degradation once added to soil (Sanaullah et al., 2010). However, recent studies found faster turnover for lignin phenols than for total SOM, and consequently different mechanisms for stabilization/degradation of lignins were proposed (Dignac et al., 2005; Thevenot et al., 2013). The hypothesis about the presence of two different pools of lignin characterized by fast and slow degradation rate, respectively, has been described by Lobe et al. (2002) and further confirmed by the model proposed by Rasse et al. (2006) in which $92 \%$ of lignin derived compounds are not stabilized within the soil matrix and, thus, quickly degraded. Therefore, a molecular study of lignin fate in soil constitutes a valid approach to the understanding of SOM behaviour (Heim and Schmidt, 2007a).

We hypothesized that ley grassland rotation could improve the net carbon storage at mid- to long-term, changing the dynamics of SOM accrual. Furthermore, we hypothesized that changes in land-use affect the SOM dynamics in specific compartments of the soil matrix so that the overall effect could be hidden when complete soil is analysed, as summarized in Fig. 1. Long term studies investigating soil organic matters dynamics in ley grassland rotations are scarce and showed contrasting effects related to the type of rotation (Studdert et al., 1997), but no available studies have been targeted to the molecular level.

This experiment consisted of maize cropping as in continuous monoculture or as part of temporary grassland. The treatments were established on fields previously cultivated with C3 plants to label by in situ natural ${ }^{13} \mathrm{C}$ enrichment the litter input during the cropland phase. We sampled soils, which had been for 9 years under permanent grassland (I), or under permanent cropland (II), left bare for 9 years (III) and under temperate grassland for 6 years (IV). The latter treatment was sampled after the 3 years of crop in order to detect the legacy effect of the ley grassland. The presence of bare fallow plots permitted to compare the persistence of SOM and its allocation within the soil aggregates in absence of fresh inputs and soil perturbation, against the three different treatment analysed. Soil aggregates were isolated to overcome soil matrix complexity using a hierarchical approach. We analysed bulk soil and aggregate samples for stable carbon isotopes as well as lignin biomarkers.

The aims of this study were to (I) explore soil fractions of water stable aggregates to investigate how land-use with changing quantity and quality of litter input (bare fallow, continuous cropping, ley and

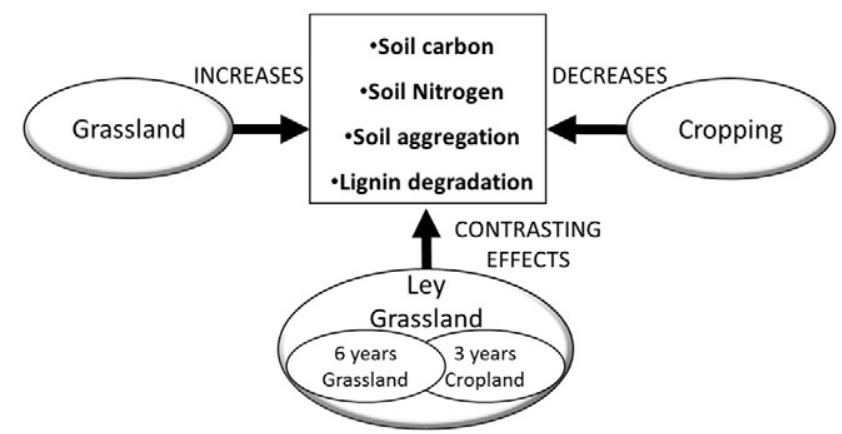

Fig. 1. Simplified schema of interactions between different land-uses and soil parameters analysed in this study. 
permanent grassland) affects the allocation and turnover of SOM within the hierarchical organisation of the soil matrix; (II) to analyse the legacy effect of ley grassland introduction into the cropping cycle in terms of protection of different SOM types within different aggregate fractions.

\section{Materials and methods}

\subsection{Experimental area}

We sampled soil from a long-term field experiment (SOERE-ACBB: Systems of Observation and Experimentation in Environmental Research-Agro-ecosystem, Biogeochemical Cycles and Biodiversity) at the INRA experimental station located near Lusignan $\left(46^{\circ} 4^{\prime} \mathrm{N}, 0^{\circ} 1^{\prime} \mathrm{E}\right)$ in western France. The soil is a cambisol with loamy texture (105 g $\mathrm{kg}^{-1}$ sand, $727 \mathrm{~g} \mathrm{~kg}^{-1}$ silt and $168 \mathrm{~g} \mathrm{~kg}^{-1}$ clay), $\mathrm{a} \mathrm{pH}_{(\mathrm{H} 2 \mathrm{O})}=6.3$ and an organic carbon content of $11 \mathrm{~g} \mathrm{~kg}^{-1}$ in the arable layer, $0-30 \mathrm{~cm}$ depth (Moni et al., 2010).The area has a temperate climate with a mean annual temperature of $10.5{ }^{\circ} \mathrm{C}$ and mean annual precipitations around $600-700 \mathrm{~mm}$.

Until 2005, prior to the establishment of this experiment, the area has been devoted to agricultural practices for at least 70 years, and hosted previously an oak forest (Senapati et al., 2014). The initial carbon signature of the soil, before the setup of the rotation was about $-25.0 \%$, thus dominated by C3 derived SOM (Chabbi et al., 2009). For this experiment 4 treatments were selected: (I) permanent grassland treatment (TG) plots of about $4000 \mathrm{~m}^{2}$ in which Lolium perenne (Cv Milca), Festuca arundinacea (Cv Soni), and Dactylis glomerata (Cv Ludac) compose the dominant vegetation, (II) ley grassland (LG), in which 6 years of prairie grassland as in PG are alternated with 3 years of cropland, (III) permanent cropland (PC), and (IV) bare fallow (BS) subplots of $54 \mathrm{~m}^{2}$ each with no vegetation. For the LG and PC treatments, only the subplots of about 500-700 $\mathrm{m}^{2}$ under maize Zea mays (L.) monocropping with $\mathrm{N}$ fertilization were selected. Each treatment has 4 plots considered as field replicates, organized in a completely randomized experimental design. Fertilizer rate and date of application were targeted at nitrogen nutrition index (NNI) of 0.9-1.0 for grassland (Lemaire et al., 2008) whereas $\mathrm{N}$ fertilization for cropped plots followed the local agronomic practices. On average, plots under grassland received $240 \mathrm{~kg}$ of $\mathrm{N} \mathrm{ha}^{-1}$ and plots under maize were fertilized with an average of $98 \mathrm{~kg}_{\mathrm{g} \mathrm{N} \mathrm{ha}}{ }^{-1}$. In the period under evaluation (2005 to 2014), permanent grassland received a total of $2160 \mathrm{~kg}$ of $\mathrm{N} \mathrm{ha}^{-1}$, whereas ley grassland and permanent cropland received 1681 and $885 \mathrm{~kg}$ of $\mathrm{N} \mathrm{ha}^{-1}$, respectively (Kunrath et al., 2015). Grasslands were subjected to regular mowing and hay harvesting three times per year. Tillage procedures for cropland plots involved mouldboard ploughing with topsoil/subsoil inversion at $25-30 \mathrm{~cm}$ depth, cultivation of one maize crop per year, and harvesting.

\subsection{Sampling}

Samples were collected in July 2014, during the last cropland year of the ley grassland plots and before the maize harvest. Soil was sampled at a $0-30 \mathrm{~cm}$ depth, comprising the arable layer, using stainless steel cylinders in order to allow the minimum disruption of soil aggregates. Five soil cores were collected at each plot and merged to obtain a composite sample per plot, with 4 replicates for treatment for a total of 16 samples. Water content of bulk soil samples was measured right after the sampling, then soil was dried at room temperature. Results regarding root and shoot inputs in cropland and grassland plots are referred to samples collected in triplicate, oven dried at $60^{\circ} \mathrm{C}$ and ground to a fine powder $(\varnothing<100 \mu \mathrm{m})$.

\subsection{Aggregate fractionation}

Water stable aggregates were isolated from bulk soil samples using the method of Elliott (1986) modified by Le Bissonnais (1996). Briefly, $50 \mathrm{~g}$ of dried sample were passed through a $7.1 \mathrm{~mm}$ mesh sieve. Bigger clods and plant residues were discarded and only material $\varnothing<7.1 \mathrm{~mm}$ was retained and allowed to slowly slake for capillarity on a sand/kaolinite basin for $1 \mathrm{~h}$. Successively, soil was placed on a $2 \mathrm{~mm}$ mesh sieve, submerged in deionised water and sieved for 2 min oscillating the sieve 50 times with a vertical excursion of $3 \mathrm{~cm}$. Soil retained on the top of the $2 \mathrm{~mm}$ sieve represented the larger macroaggregates fraction (LMA, ø 2-7.1 mm). The procedure was repeated with the soil suspension containing the other fractions, using $0.200 \mathrm{~mm}$ and then 0.050 mesh sieves to separate macroaggregates (MA, ø $0.200-2 \mathrm{~mm}$ ), microaggregates (miA, ø 0.050-0.200) and silt + clay (S + C, $\emptyset<0.050 \mathrm{~mm}$ ) fractions. Samples were freeze dried, finely ground and stored for further analyses. Aggregate separation process revealed a $98 \%$ of average recovery, with $93 \%$ as the lowest obtained value. In total, 4 fractions were collected for each treatment and replicate, for a total of 64 aggregate fraction samples.

\subsection{Chemical and isotopic analyses}

Carbon and nitrogen content, together with ${ }^{13} \mathrm{C}$ isotopic signature, of bulk soil and aggregates samples were measured using an elemental analyser (CHN NA 1500, Carlo Erba) coupled with an isotopic ratio mass spectrometer (VG Sira 10, Girardin and Mariotti, 1991). The laboratory reference is calibrated against the international standard VPDB. Results were expressed as $\delta^{13} \mathrm{C}$, the isotopic ratio $\left({ }^{13} \mathrm{C} /{ }^{12} \mathrm{C}\right)$ relative to the standard (VPDB):

$\delta^{13} \mathrm{C}=\left(\frac{\left({ }^{13} \mathrm{C} /{ }^{12} \mathrm{C}\right)_{\text {sample }}}{\left({ }^{13} \mathrm{C} /{ }^{12} \mathrm{C}\right)_{\mathrm{VPDB}}}-1\right) \times 1000$

The turnover of total SOM can be therefore quantified using the ${ }^{13} \mathrm{C}$ enrichment provoked by maize crops in plots under permanent cropland and ley grassland. The $\delta^{13} \mathrm{C}$ signature was expressed using the equation of Balesdent and Mariotti (1996), simplified as described by Dignac et al. (2005):

$F=\frac{\mathrm{TOC}_{\text {newM }}}{\mathrm{TOC}_{\mathrm{M}}}=\frac{\delta_{\mathrm{M}}-\delta_{\mathrm{G}}}{\delta_{\text {newM }}-\delta_{\text {newG }}}$

in which TOC stands for total carbon of the soil or the analysed fraction, and $\mathrm{TOC}_{\text {new }}$ for the carbon derived from the new vegetation, and similarly for the isotope ratio $\delta$. The subscripts ${ }_{M}$ and ${ }_{G}$ stand for the two plots under maize (permanent cropland, after 9 years of maize and ley grassland, after 3 years of maize) and permanent grassland, respectively. To estimate the term $\left(\delta_{\text {newm }}-\delta_{\text {newG }}\right)$, the difference in isotopic composition between plant materials was used. The relative proportions of biomass inputs from roots and shoots (Table 2 ) have been used to estimate $\delta_{\text {newm }}$ and $\delta_{\text {new }}$ as the weighted average of the corresponding isotopic signatures of plant organs.

TOC decomposition is assumed to follow first order kinetics and the percentage of new carbon can be used to estimate $C_{\text {org }}$ turnover times, which is the inverse of the decay constant, $k$ according to the simplified equation used by Balesdent et al. (1990):

$T=\frac{1}{k}=-\frac{t}{\ln (1-F)}$

where $T$ is the turnover time (years), $k$ is the decay constant (year ${ }^{-1}$ ), $t$ is the number of years of maize cultivation (years), and $F$ is the fraction of new carbon in soil.

\subsection{Lignin characterization}

An alkaline oxidation by $\mathrm{CuO}$ was carried out using $500 \mathrm{mg}$ of each soil sample (50 mg for plant material) to release phenol monomers from lignin (Hedges and Ertel, 1982; Kögel and Bochter, 1985). 
Purification of the extracts was achieved by precipitation of humic acids followed by solid-phase extraction with $1 \mathrm{~g}$ SPME REC18-columns, which were rinsed with ethyl acetate to elute and collect the monophenols. To check for sample losses during experimental procedure, ethylvanillin was added as recovery standard before the purification steps. A solution of internal standard phenylacetic acid in pyridine was used to take up dried samples.

Monophenols were derivatised by BSTFA (N,OBis(trimethylsilyl)trifluoroacetamide) and quantified using a Hewlett Packard gas chromatograph (HP GC 6890) equipped with a flame ionisation detector (GC-FID) and a SGE BPX-5 column $(65.0 \mathrm{~m} \times$ $320 \mu \mathrm{m}$ ID, $0.25 \mu \mathrm{m}$ film thickness, SGE, Australia). Helium was used as carrier gas with a constant flow of $1 \mathrm{ml} \mathrm{min}^{-1}$. Temperature specifications were as follows: injector was set at $280^{\circ} \mathrm{C}$ and detector was set at $350{ }^{\circ} \mathrm{C}$, temperature program: $100{ }^{\circ} \mathrm{C}$ hold for $2 \mathrm{~min}, 8{ }^{\circ} \mathrm{C} \mathrm{min}{ }^{-1}$ to $172{ }^{\circ} \mathrm{C}, 4^{\circ} \mathrm{C} \min ^{-1}$ to $184{ }^{\circ} \mathrm{C}, 10^{\circ} \mathrm{C} \mathrm{min}^{-1}$ to $310^{\circ} \mathrm{C}$, hold for $5 \mathrm{~min}$.

Lignin monophenol concentration was calculated using standard mixtures of vanillin, acetovanillone and vanillic acid for the vanillyl (V)-type lignin units, syringaldehyde, acetosyringone, syringic acid for the syringyl (S) units, and p-coumaric acid and ferulic acid for cinnamyl (C)-type units. A sum of VSC units represented the total lignin content. The acid to aldehyde mass ratios $(\mathrm{Ac} / \mathrm{Al}) \mathrm{V}$ and $(\mathrm{Ac} / \mathrm{Al}) \mathrm{S}$, together with the mass ratios $\mathrm{S} / \mathrm{V}$ and $\mathrm{C} / \mathrm{V}$ were used as indicators of lignin degradation (Hedges and Ertel, 1982).

\subsection{Statistical analyses}

Data normality was tested by the Shapiro-Wilk test. Significant differences between treatments were analysed by running a univariate analysis of variance (ANOVA) and subsequently a Tuckey test to test whether there was a significant ( $\mathrm{p} \leq 0.05)$ effect of the land-use on each one of the studied variables. Due to data dispersion obtained for lignin analyses, a two-way ANOVA was conducted that examined the effect of methodological reproducibility and treatment on VSC content. Only statistically significant differences originated by treatments are shown in figures $(\mathrm{p} \leq 0.05)$.

The correlation table of all soil parameters was based on Pearson correlation coefficients $(p<0.05)$. Data were also treated by a Principal Component Analysis (PCA) to examine variation with respect to the different measured parameters. PCA was forced to generate only three eigenvalues. Statistical analyses were carried out using R software, Version 3.2.4-Revised (R Development CoreTeam 2016).

\section{Results}

\subsection{Plant litter returned to soil}

Estimated plant litter inputs returned to soil for grassland were calculated according to Sanaullah et al. (2010) for the same experimental area. Mowing procedures reduced the aboveground litter returned to soil (shoots and leaves) to $20 \%$ of the total aboveground biomass produced. Nevertheless, total plant litter returned yearly to soil was estimated to be higher for soil under grassland than for soil under maize (Table 1 ).

Grassland inputs were mainly composed by root material, whereas maize crops returned a higher proportion of shoots derived material. Carbon and nitrogen contents of plant samples were similar between maize and grass species, therefore the quantity of $\mathrm{C}_{\text {org }}$ and $\mathrm{N}$ returned to soil was directly proportional to the quantity of litter for each treatment. The lignin content of maize samples was twice higher than the corresponding grassland samples, therefore maize soils received yearly 2 to 3-times more lignin than soils under grassland, but most of it as shoots derived material. Moreover, the amounts of TOC, TON and VSC were significantly correlated with the amount of litter and lignin returned as root material, but not with the inputs from shoots (Table 2).

\subsection{Distribution of $C$ and $N$ in aggregate fractions}

The distribution of aggregate size fractions was similar for all the treatments, with high dispersion of the data attributable to the wide dimension of the experimental plots (Table 3 ).

Macroaggregates (ø $0.200-2 \mathrm{~mm}$ ) were the most abundant fraction, comprising from 35 to $50 \%$ of total soil dry weight. Compared to soil under cropland and grassland, bare fallow plots showed a decrease in the relative contribution of larger macroaggregates (LMA, ø 2$7.1 \mathrm{~mm}$ ) to total soil mass, compensated by a shift to higher relative abundance of macroaggregates (MA) and microaggregates (miA, $0.050-0.200 \mathrm{~mm}$ ).

Contents of TOC and C4 derived SOM (calculated using $F$ values from Eq. (2)) in the different fractions are represented in Fig. 2A. The TOC contents of bare fallow (BS) plots were significantly lower for bulk soil samples and all the analysed fractions compared to the other treatments, except for the silt plus clay fraction $(S+C, \varnothing<0.050 \mathrm{~mm})$. Agricultural treatments did not lead to contrasting TOC contents of bulk soil, whereas for larger macroaggregates $(\varnothing 2-7.1 \mathrm{~mm}$ ) both ley and permanent grassland showed significantly higher TOC contents compared to permanently cropped plots. TOC content of permanent grassland was also significantly higher than that of permanent cropland for the macroaggregates fraction (ø $0.200-2 \mathrm{~mm}$ ). The contents of TON for bulk samples showed the same pattern as TOC, with a significant decrease for bare fallow and no effect induced by agricultural management (Table 3). TOC and TON were strongly and significantly correlated among each other $\left(R^{2} 0.811\right)$, therefore tendencies and distributions registered for TOC in aggregate fractions were similar to those observed for TON, but no statistical significances were found for the latter (Table 3, Fig. $2 \mathrm{~B}$ and $\mathrm{C}$ ). The highest percentage ( 35 to $60 \%$ ) of TOC and TON were accumulated in macroaggregates (ø $0.200-2 \mathrm{~mm}$ ), for all four treatments. Significantly lower values were found in larger macroaggregates (ø 2-7.1 mm) of bare fallow plots compared to the three plots under cropland. Significantly higher contents of TOC and TON were found in macroaggregates (ø $0.200-2 \mathrm{~mm}$ ) of permanent cropland if compared with permanent grassland ones, whereas results for the other fractions showed no differences.

Table 1

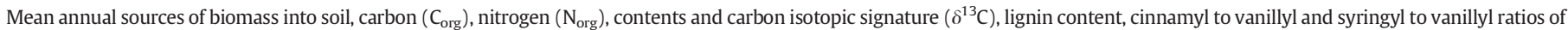
grassland plants at the SOERE-ACBB site in Lusignan (France).

\begin{tabular}{|c|c|c|c|c|}
\hline & Maize roots & Maize shoots & Grass roots & Grass shoots \\
\hline Mean annual sources of biomass into soil $\left(\mathrm{t} \mathrm{ha}^{-1}\right)$ & $1.08 \pm 0.48$ & $7.15 \pm 3.26$ & $9.31 \pm 3.54$ & $\begin{array}{l}1.94 \pm 0.81 \\
\text { (estimated by Sanaullah et al., 2010) }\end{array}$ \\
\hline $\mathrm{C}_{\mathrm{org}}\left(\mathrm{g} \mathrm{kg}^{-1}\right)$ & $342 \pm 4$ & $418 \pm 1$ & $326 \pm 19$ & $433 \pm 60$ \\
\hline $\mathrm{N}_{\text {org }}\left(\mathrm{g} \mathrm{kg}^{-1}\right)$ & $9.1 \pm 0.9$ & $6.8 \pm 0.1$ & $11.4 \pm 1.2$ & $24.9 \pm 7.6$ \\
\hline $\mathrm{C}_{\text {org }} / \mathrm{N}_{\text {org }}$ & $37.7 \pm 3.8$ & $61.7 \pm 0.5$ & $28.7 \pm 3.0$ & $17.5 \pm 6.5$ \\
\hline$\delta^{13} \mathrm{C}$ signature (\%) & $-13.23 \pm 0.42$ & $-12.94 \pm 0.25$ & $-29.00 \pm 0.16$ & $-27.19 \pm 1.16$ \\
\hline Lignin $\left(\mathrm{g} \mathrm{kg}^{-1}\right)$ & $23.8 \pm 0.3$ & $20.3 \pm 1.6$ & $8.7 \pm 1.8$ & $9.8 \pm 2.4$ \\
\hline Lignin $\mathrm{C} / \mathrm{V}$ ratio & $3.01 \pm 0.35$ & $1.28 \pm 0.44$ & $0.88 \pm 0.80$ & $1.69 \pm 0.83$ \\
\hline Lignin $\mathrm{S} / \mathrm{V}$ ratio & $2.25 \pm 0.12$ & $1.56 \pm 0.01$ & $1.33 \pm 0.34$ & $1.42 \pm 0.26$ \\
\hline
\end{tabular}

$\mathrm{n}=4$; mean values and standard deviations. 
Table 2

Pearson's correlation table for the analysed parameters.

\begin{tabular}{|c|c|c|c|c|c|c|c|c|c|c|c|c|c|c|c|c|c|c|c|c|}
\hline Variables & $(\mathrm{Ac} / \mathrm{Al}) \mathrm{V}$ & $(\mathrm{Ac} / \mathrm{Al}) \mathrm{S}$ & $\mathrm{C} / \mathrm{V}$ & $S / \mathrm{V}$ & VSC/TOC & VSC/TON & TOC & TON & TOC/TON & $\begin{array}{l}\text { Aggregate } \\
\text { distribution }\end{array}$ & $\delta^{13} \mathrm{C}$ & $\begin{array}{l}\text { Total } \\
\text { litter }\end{array}$ & $\begin{array}{l}\text { Roots } \\
\text { litter }\end{array}$ & $\begin{array}{l}\text { Shoots } \\
\text { litter }\end{array}$ & $\begin{array}{l}\text { Total } \\
\text { lignin }\end{array}$ & $\begin{array}{l}\text { Lignin } \\
\text { from roots }\end{array}$ & $\begin{array}{l}\text { Lignin from } \\
\text { shoots }\end{array}$ & $\begin{array}{l}\text { VSC } \\
\text { distribution }\end{array}$ & $\begin{array}{l}\text { TON } \\
\text { distribution }\end{array}$ & $\begin{array}{l}\text { TOC } \\
\text { distribution }\end{array}$ \\
\hline VSC & $-0.538^{*}$ & $-0.487^{*}$ & $0.270^{*}$ & $0.307^{*}$ & $0.497^{*}$ & $0.513^{*}$ & $0.442^{*}$ & $0.376^{*}$ & 0.158 & 0.047 & $-0.246^{*}$ & $0.564^{*}$ & $0.513^{*}$ & 0.194 & $0.370^{*}$ & $0.537^{*}$ & 0.109 & 0.037 & 0.049 & 0.045 \\
\hline$(\mathrm{Ac} / \mathrm{Al}) \mathrm{V}$ & & $0.630^{*}$ & 0.083 & $-0.367^{*}$ & $-0.265^{*}$ & -0.214 & -0.014 & -0.045 & 0.059 & $-0.280^{*}$ & 0.065 & $-0.222^{*}$ & -0.205 & -0.069 & -0.131 & -0.195 & -0.036 & $-0.271^{*}$ & $-0.272^{*}$ & $-0.269^{*}$ \\
\hline$(\mathrm{Ac} / \mathrm{Al}) \mathrm{S}$ & & - & -0.154 & -0.187 & $-0.299^{*}$ & $-0.399^{*}$ & -0.152 & 0.095 & $-0.376^{*}$ & -0.020 & 0.103 & $-0.327^{*}$ & $-0.359^{*}$ & -0.017 & -0.148 & $-0.348^{*}$ & 0.032 & -0.026 & -0.003 & -0.013 \\
\hline $\mathrm{C} / \mathrm{V}$ & & & - & $0.568^{*}$ & $0.231^{*}$ & $0.426^{*}$ & 0.205 & -0.188 & $0.682^{*}$ & $-0.386^{*}$ & 0.213 & 0.177 & 0.067 & 0.206 & $0.225^{*}$ & 0.109 & 0.191 & $-0.369^{*}$ & $-0.398^{*}$ & $-0.372^{*}$ \\
\hline $\mathrm{s} / \mathrm{V}$ & & & & - & 0.127 & $0.246^{*}$ & 0.101 & -0.035 & $0.273^{*}$ & -0.169 & $0.333^{*}$ & 0.134 & -0.079 & $0.352^{*}$ & $0.302^{*}$ & -0.026 & $0.354^{*}$ & -0.168 & -0.174 & -0.167 \\
\hline VSC/TOC & & & & & - & $0.857^{*}$ & $0.362^{*}$ & $0.268^{*}$ & 0.181 & 0.054 & -0.169 & $0.338^{*}$ & $0.274^{*}$ & 0.168 & $0.259^{*}$ & $0.295^{*}$ & 0.122 & 0.122 & 0.064 & 0.077 \\
\hline VSC/TON & & & & & & - & $0.461^{*}$ & 0.182 & $0.485^{*}$ & -0.148 & -0.023 & $0.424^{*}$ & $0.265^{*}$ & $0.331^{*}$ & $0.415^{*}$ & $0.324^{*}$ & $0.282^{*}$ & -0.070 & -0.141 & -0.114 \\
\hline TOC & & & & & & & - & $0.811^{*}$ & $0.443^{*}$ & -0.114 & $-0.354^{*}$ & $0.637^{*}$ & $0.617^{*}$ & 0.162 & $0.378^{*}$ & $0.638^{*}$ & 0.062 & -0.026 & -0.068 & -0.043 \\
\hline TON & & & & & & & & - & -0.148 & 0.161 & $-0.353^{*}$ & $0.544^{*}$ & 0.504 & 0.173 & 0.344 & 0.527 & 0.086 & 0.215 & 0.215 & 0.210 \\
\hline TOC/TON & & & & & & & & & - & $-0.419^{*}$ & -0.014 & $0.267^{*}$ & $0.272^{*}$ & 0.049 & 0.151 & $0.282^{*}$ & 0.009 & $-0.357^{*}$ & $-0.427^{*}$ & $-0.379^{*}$ \\
\hline $\begin{array}{l}\text { Aggregate } \\
\text { distribution }\end{array}$ & & & & & & & & & & - & 0.038 & -0.009 & -0.009 & -0.001 & -0.004 & -0.009 & 0.001 & $0.986^{*}$ & $0.996^{*}$ & $0.993^{*}$ \\
\hline$\delta^{13} \mathrm{C}$ & & & & & & & & & & & - & -0.188 & $-0.631^{*}$ & $0.638^{*}$ & $0.380^{*}$ & $-0.511^{*}$ & $0.717^{*}$ & 0.015 & 0.019 & 0.021 \\
\hline Total litter & & & & & & & & & & & & - & $0.819^{*}$ & $0.483^{*}$ & $0.774^{*}$ & $0.912^{*}$ & $0.349^{*}$ & 0.000 & 0.000 & 0.000 \\
\hline Roots litter & & & & & & & & & & & & & - & -0.107 & $0.272^{*}$ & $0.977^{*}$ & $-0.251^{*}$ & 0.000 & 0.000 & 0.000 \\
\hline Shoots litter & & & & & & & & & & & & & & - & $0.927^{*}$ & 0.090 & $0.989^{*}$ & 0.000 & 0.000 & 0.000 \\
\hline Total lignin & & & & & & & & & & & & & & & - & $0.457^{*}$ & $0.862^{*}$ & 0.000 & 0.000 & 0.000 \\
\hline $\begin{array}{l}\text { Lignin from } \\
\text { roots }\end{array}$ & & & & & & & & & & & & & & & & - & -0.056 & 0.000 & 0.000 & 0.000 \\
\hline $\begin{array}{l}\text { Lignin from } \\
\text { shoots }\end{array}$ & & & & & & & & & & & & & & & & & - & 0.000 & 0.000 & 0.000 \\
\hline $\begin{array}{l}\text { VSC } \\
\text { distribution }\end{array}$ & & & & & & & & & & & & & & & & & & - & $0.992^{*}$ & $0.996^{*}$ \\
\hline $\begin{array}{l}\text { TON } \\
\text { distribution }\end{array}$ & & & & & & & & & & & & & & & & & & & - & $0.998^{*}$ \\
\hline
\end{tabular}

$\mathrm{n}=4$; significant correlation at $\mathrm{p}<0.05$ are marked with asterisks. 
Table 3

Aggregates distribution, total organic nitrogen (TON) contents and carbon to nitrogen (C) $\mathrm{N}$ ) values of soil at the SOERE-ACBB site in Lusignan (France).

\begin{tabular}{lllll}
\hline Fraction & Treatment & $\begin{array}{l}\text { Aggregate contribution } \\
\text { (\% of total soil) }\end{array}$ & $\begin{array}{l}\text { TON } \\
\left(\mathrm{g} \mathrm{kg}^{-1}\right)\end{array}$ & $\mathrm{C} / \mathrm{N}$ \\
\hline Bulk soil & PC & & $1.20 \pm 0.16 \mathbf{b}$ & $8.62 \pm 0.72$ \\
& TG & & $1.30 \pm 0.18 \mathbf{b}$ & $8.75 \pm 0.59$ \\
& PG & & $1.31 \pm 0.06 \mathbf{b}$ & $8.81 \pm 0.29$ \\
& BS & & $0.93 \pm 0.06 \mathbf{a}$ & $8.20 \pm 0.31$ \\
LMA & PC & $17.79 \pm 8.99$ & $0.82 \pm 0.18 \mathbf{a b}$ & $10.98 \pm 1.13$ \\
& TG & $16.09 \pm 7.92$ & $0.95 \pm 0.08 \mathbf{b c}$ & $12.82 \pm 2.44$ \\
& PG & $13.98 \pm 6.69$ & $1.16 \pm 0.12 \mathbf{c}$ & $12.33 \pm 1.25$ \\
& BS & $6.51 \pm 2.41$ & $0.59 \pm 0.14 \mathbf{a}$ & $10.85 \pm 1.46$ \\
MA & PC & $49.09 \pm 4.05$ & $1.18 \pm 0.11 \mathbf{a b}$ & $9.61 \pm 0.46$ \\
& TG & $41.92 \pm 12.38$ & $1.37 \pm 0.24 \mathbf{b}$ & $9.98 \pm 0.88$ \\
& PG & $34.45 \pm 9.80$ & $1.37 \pm 0.07 \mathbf{b}$ & $10.49 \pm 0.35$ \\
micA & BS & $49.61 \pm 14.51$ & $0.98 \pm 0.05 \mathbf{a}$ & $9.15 \pm 0.95$ \\
& PC & $11.91 \pm 2.13$ & $1.22 \pm 0.15$ & $9.54 \pm 0.36 \mathrm{ab}$ \\
& TG & $12.72 \pm 5.22$ & $1.40 \pm 0.21$ & $9.98 \pm 0.72 \mathrm{ab}$ \\
& PG & $14.75 \pm 6.74$ & $1.37 \pm 0.33$ & $10.33 \pm 0.61 \mathrm{~b}$ \\
& BS & $19.51 \pm 8.41$ & $1.07 \pm 0.13$ & $8.56 \pm 1.07 \mathbf{a}$ \\
S + C & PC & $19.79 \pm 7.25$ & $1.01 \pm 0.11$ & $8.38 \pm 0.58$ \\
& TG & $28.09 \pm 14.61$ & $1.14 \pm 0.12$ & $8.39 \pm 0.70$ \\
& PG & $32.34 \pm 12.43$ & $1.16 \pm 0.20$ & $8.30 \pm 1.11$ \\
& BS & $24.66 \pm 7.45$ & $0.95 \pm 0.08$ & $8.31 \pm 0.15$
\end{tabular}

$\mathrm{n}=4$; mean values and standard deviations. Significant differences at $\mathrm{p}<0.05$ are marked with different letters. PC: permanent cropland; TG: ley grassland; PG: permanent grassland; BS: bare soil.

Carbon to nitrogen ratios were significantly different between treatments only for microaggregates (ø $0.200-2 \mathrm{~mm}$ ) in which values of cropped and grassland soils were higher than those for bare fallows. For the other fractions, similar trends were observed, but no significant differences appeared between treatments (Table 3).

\section{3. ${ }^{13} \mathrm{C}$ signature changes with aggregate size and land management}

The $\delta^{13} \mathrm{C}$ signatures of plant litter are reported in Table 1 and those of soil fractions in Fig. 3A. The adoption of continuous C4 maize cultivation on soil previously cropped with $\mathrm{C} 3$ plants provoked significant increases in $\delta^{13} \mathrm{C}$ signature of SOM in permanently cropped plots if compared to both permanent and ley grassland ones (Fig. 3A). An increase of $\delta^{13} \mathrm{C}$ signature was detected also for bare fallow plots, in which the isotopic fractionation during the decomposition of residual SOM was not counteracted by fresh litter inputs. For the aggregate fractions, permanent cropland soils showed significantly higher $\delta^{13} \mathrm{C}$ values than ley grassland ones, which showed, in turn, significantly higher values than permanent grassland soils. The latter condition was not significant for silt plus clay fraction $(\varnothing<0.050 \mathrm{~mm})$. Plots left bare showed significant ${ }^{13} \mathrm{C}$ enrichment for bulk soil and aggregates as compared to permanent grassland, except for the silt plus clay fraction $(\varnothing<0.050 \mathrm{~mm})$.

The $\delta^{13} \mathrm{C}$ values decreased with aggregate size under permanent maize. Similar results were found for plots under ley grassland and for bare fallow samples, which showed higher ${ }^{13} \mathrm{C}$ contents than the corresponding samples under permanent grassland, except for the silt plus clay fraction $(\varnothing<0.050 \mathrm{~mm})$.

\subsection{Estimate of maize derived $C_{\text {org }}$ incorporation}

The Eq. (2) has been used to estimate the newly incorporated SOM $(F)$ for plots subjected to either temporary ( 3 years) or permanent ( 9 years) maize cultivation and represented as percentage of TOC in Fig. 2A. Contribution of C4 SOM decreased with aggregate size for both treatments and ranged from $25 \%$ for larger macroaggregates (ø 2$7.1 \mathrm{~mm}$ ) of permanent cropland soil to $1.2 \%$ measured for silt plus clay fraction $(\varnothing<0.050 \mathrm{~mm}$ ) of ley grassland soil.

With these data, the mean residence times of organic carbon in the different fractions were estimated using Eq. (3) (Fig. 3B). Mean residence time of $\mathrm{C}_{\text {org }}$ showed similar tendencies throughout the fractions for both permanent cropland and ley grassland soils. The only significant difference was found for silt plus clay fraction, in which $\mathrm{C}_{\text {org }}$ mean residence time of ley grassland soil was twice higher than for permanent cropland soil.

\subsection{Lignin molecular composition}

Distribution of lignin phenols throughout the aggregate fractions showed no differences between cultivated soils, but for bare fallow soils, $<5 \%$ of the VSC was detected in larger macroaggregates ( $\varnothing 2-$ $7.1 \mathrm{~mm})$, compensated by a higher proportion detected in macroaggregates (ø $0.200-2 \mathrm{~mm})$ and microaggregates $(\varnothing 0.050-0.200 \mathrm{~mm})$ as compared to the other treatments (Fig. 2E).

The contents of total lignin (VSC) for bulk samples and for all the fractions analysed are represented in Fig. 2E. For the larger macroaggregates (ø 2-7.1 mm) significantly lower VSC to $C_{\text {org }}$ ratio was observed for bare fallow samples compared to the other treatments, whereas the two-way ANOVA highlighted a significantly higher lignin contribution to TOC for permanent grassland treatment as compared to permanent cropland. The contribution of VSC to TON was similar for all the treatments for bulk soil (Fig. 2F), whereas permanent and ley grassland had significantly higher ratios than cropland for larger macroaggregates (ø 2-7.1 mm) fraction. Bare fallow samples showed the lowest values for VSC to TON in larger macroaggregates and macroaggregates.

Maize roots showed the highest $\mathrm{C} / \mathrm{V}$ and $\mathrm{S} / \mathrm{V}$ ratios, whereas the lowest ratios were found for grass roots (Table 1). The composition of the lignin extracted from the soil samples differed between treatments only for larger aggregate fractions. Effects of cultivation were significant for larger macroaggregates (ø 2-7.1 mm), for which ley grassland showed higher $\mathrm{C} / \mathrm{V}$ and $\mathrm{S} / \mathrm{V}$ ratios than permanent grassland. Bulk samples of permanent maize showed higher $\mathrm{S} / \mathrm{V}$ ratios compared to the other treatments, but no differences between treatments were found for $\mathrm{C} / \mathrm{V}$ ratios (Fig. $4 \mathrm{~A}$ and $\mathrm{B}$ ).

Acid to aldehyde ratios calculated for $\mathrm{V}$ and $\mathrm{S}$ units were generally higher for silt plus clay fractions $(\varnothing<0.050 \mathrm{~mm}$ ) of all treatments. Both ratios were strongly correlated among them and negatively correlated with VSC contents (Table 2). Bare fallow plots showed significantly higher Ac/Al-V ratios for bulk soil when compared with plots under permanent maize, and for larger macroaggregates (ø 2-7.1 mm), if compared with corresponding ley grassland samples (Fig. 4C). Permanently cropped soil had a significantly higher ratio than ley grassland for larger macroaggregates (ø 2-7.1 mm), whereas no further differences were found for the other fractions. Regarding the $\mathrm{S}$ units, the Ac/Al-S ratio was significantly higher for permanent cropland compared to ley grassland for bulk soil, and for bare fallow compared to ley grassland for larger macroaggregates $(\varnothing 2-7.1 \mathrm{~mm})$ and to ley grassland and bare fallow for silt plus clay fraction $(\varnothing<0.050 \mathrm{~mm}$, Fig. 4D).

\section{6. $P C A$ analysis}

Three factors were selected with a principal component analysis, representing $28.1,22.2$, and $17.1 \%$ of the inertia, respectively. Based on the quality of the representation of the variables, expressed as squared cosine, the second component of the PCA analysis was defined mainly by the aggregate distribution, and by the $\mathrm{C} / \mathrm{V}$ and $(\mathrm{Ac} / \mathrm{Al}) \mathrm{V}$ ratio. The third one was defined by the $\delta^{13} \mathrm{C}$ signature and quantity of the shoot derived litter returned to soil. The other variables were grouped in the first component (Table 4).

Samples were plotted in a bi-dimensional representation using the first two factors as axes, whereas a three-dimension representation was obtained including the third factor (Fig. 5A and B). The quality of the representations of the different observations, expressed as squared cosine, are proportional to the size of the points in the graph, as reported in the figure legend.

The interpretation of the PCA plots showed how bare fallow samples shifted toward negative values of the first component, isolated from the 

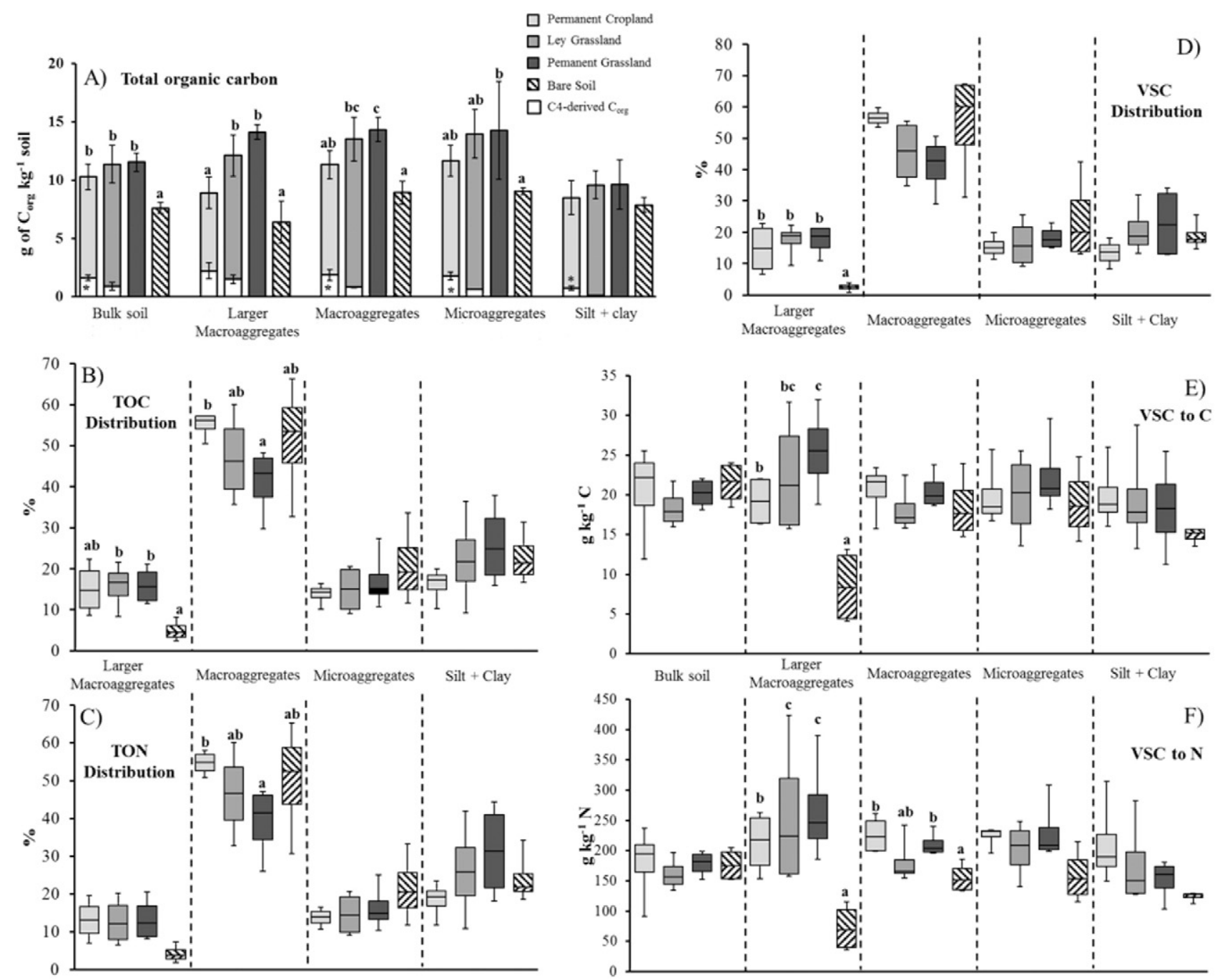

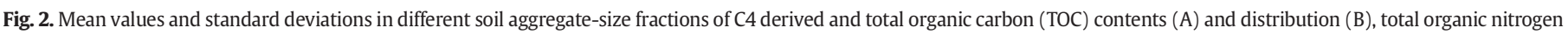

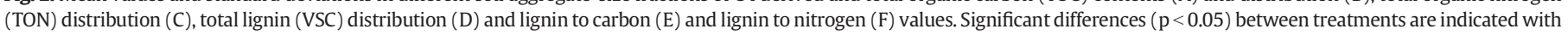
different letter.

other treatments. This means that the quality of SOM and aggregate composition was strongly affected by 9 years without any plant input.

Moreover, MA of permanent grassland and LMA of both ley and permanent grassland shifted toward positive values of the first dimension on the right of the two-dimensional plot, if compared with corresponding samples of permanent cropland. The hierarchical approach on aggregate fraction unveiled those differences, which were hardly distinguishable for the bulk soil samples, grouped together on the top centre of the figure.

The three-dimensional plot showed well defined regions for bare fallow and permanent cropland, whereas ley and permanent grassland were isolated from the other treatments, but indistinguishable among them. After three years of continuous maize, a migration of ley grassland sample toward the permanent cropland group was detected (Fig.5B), but the grassland footprint was still dominating.

\section{Discussion}

\subsection{Vegetal inputs: the driving force linking land-use and SOM dynamics}

Despite yearly inputs of $\mathrm{C}_{\text {org }}$ from vegetation were slightly higher for grassland (Table 1), no significant differences in TOC contents were found for bulk soil samples at $0-30 \mathrm{~cm}$ depth even if an increasing trend was detected for grassland and ley grassland if compared to permanent cropland, as shown in Fig. 2A. As reported by several authors, the different agronomical practices carried out for grassland and cropland soils generate two different patterns of distribution of TOC along the soil profile: stratification of SOM under unperturbed grassland soil versus SOM redistribution provoked by the full inversion tillage (Franzluebbers, 2002; Glover et al., 2010). Moreover, maize crops returned to soil a high proportion of aboveground shoots, whereas grass roots are the main litter inputs for grassland plots. According to Rasse et al. (2005), the accumulation of SOM is mainly driven by belowground litter, rather than aboveground biomass. Present data showed that TOC and lignin values were positively correlated with root derived litter inputs, but not with the shoot derived litter. Taking into account these assumptions, a significant increase of TOC would be expected under grassland treatment if compared to cropland, but was not detected for bulk soil samples under our experimental conditions. A possible explanation is given by the difference between the depth of the sampling horizon and the root distribution found along grassland soil profile. The highest amount of root biomass (i.e. root density) was found in the first $10 \mathrm{~cm}$ for the grass species of the present experiment, as reported by other studies on similar ecosystems (Jackson et al., 1996). Soil sampling comprised the top $30 \mathrm{~cm}$ of soil, corresponding to the arable perturbed by the full inversion tillage (mouldboard) for the plots under maize. Franzluebbers (2002) described that most of the variation in soil parameters provoked by changes in land-use and agronomical 


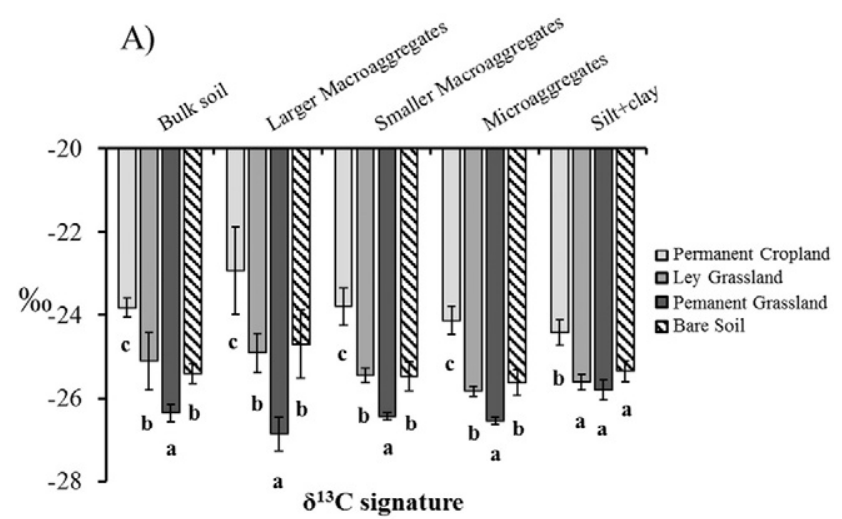

B)

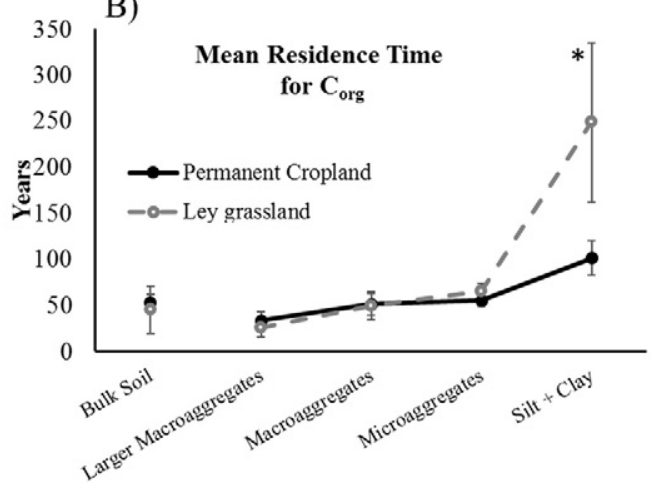

Fig. 3. Mean values and standard deviations in different soil aggregate-size fractions of $\delta^{13} \mathrm{C}$ signature (A) and mean residence time of organic carbon (B). Significant differences $(p<0.05)$ between treatments are indicated with different letter $(A)$ or with an asterisk (B).

practices are found in the arable layer. The same author evidenced how the stratification ratios of SOM are a major index of soil quality, especially for systems not perturbed by tillage, as grasslands. According to these findings, another study conducted on the same experimental area (Creme et al., personal communication), found significant differences
Table 4

Squared cosines obtained for the analysed variables in the PCA analysis.

\begin{tabular}{llll}
\hline & F1 & F2 & F3 \\
\hline VSC & 0.530 & 0.036 & 0.005 \\
(Ac/Al)V & 0.104 & 0.131 & 0.005 \\
(Ac/Al)S & 0.224 & 0.006 & 0.010 \\
C/V & 0.175 & 0.280 & 0.026 \\
S/V & 0.118 & 0.072 & 0.167 \\
VSC/TOC & 0.338 & 0.022 & 0.000 \\
VSC/TON & 0.509 & 0.009 & 0.012 \\
TOC & 0.557 & 0.008 & 0.066 \\
TON & 0.266 & 0.167 & 0.031 \\
TOC/TON & 0.234 & 0.228 & 0.015 \\
Aggregate distribution & 0.026 & 0.873 & 0.043 \\
$\delta^{13} C$ & 0.029 & 0.043 & 0.797 \\
Total litter & 0.791 & 0.030 & 0.000 \\
Roots litter & 0.503 & 0.053 & 0.308 \\
Shoots litter & 0.210 & 0.003 & 0.689 \\
Total lignin & 0.496 & 0.001 & 0.353 \\
Lignin from roots & 0.626 & 0.047 & 0.154 \\
Lignin from shoots & 0.116 & 0.008 & 0.794 \\
VSC distribution & 0.015 & 0.872 & 0.037 \\
TON distribution & 0.022 & 0.895 & 0.038 \\
TOC Distribution & 0.018 & 0.879 & 0.038 \\
\hline
\end{tabular}

between TOC contents of both ley and permanent grasslands in the topsoil layer $(0-10 \mathrm{~cm})$ when compared to permanent cropland.

\subsection{Soil aggregates respond to changes in land-use with different patterns}

In the present study, TOC increases under both ley and permanent grassland were detected only for fast responding fractions, such as larger macroaggregates ( $\varnothing 2-7.1 \mathrm{~mm}$ ), which changed after 6 years grassland, and for macroaggregate $(\varnothing 0.200-2 \mathrm{~mm})$ fractions, which are affected only after 9 years of grassland (Fig. 2A).

Three years of maize cultivation in the temporary grassland soil did not generate any significant decrease of the TOC previously accumulated under six years of grassland for larger macroaggregates, macroaggregates and microaggregates compared to the corresponding permanent grassland fractions. Nevertheless, the change in land-use from grassland to cropland led to a trend toward lower amount of $\mathrm{C}_{\text {org }}$ for the same

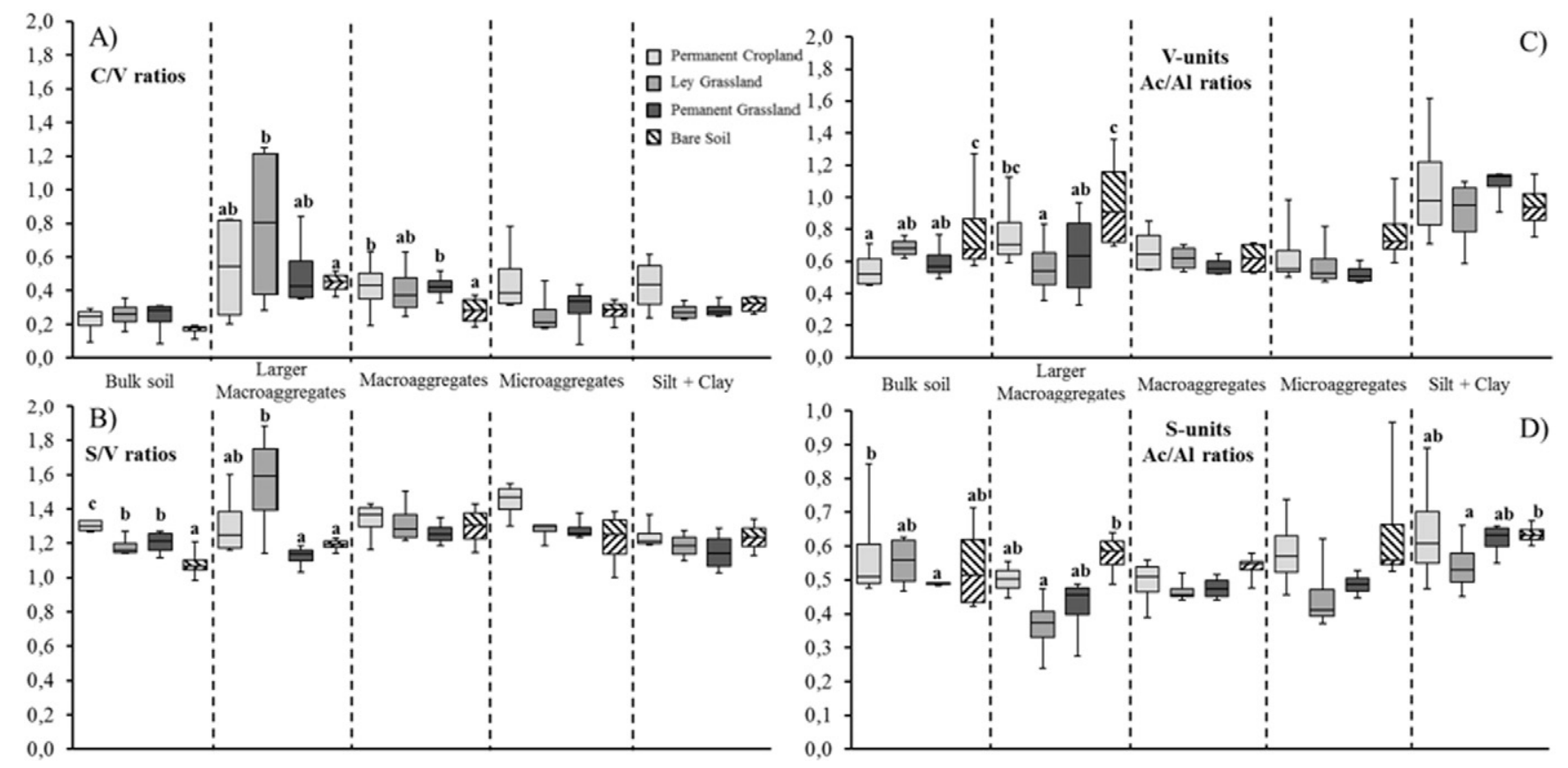

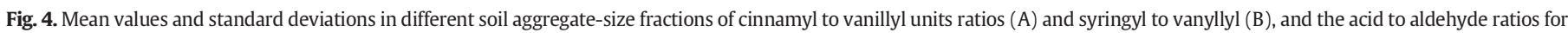
vanillyl and syringyl units ( $C$ and $D)$. Significant differences $(\mathrm{p}<0.05)$ between treatments are indicated with different letter. 
A)

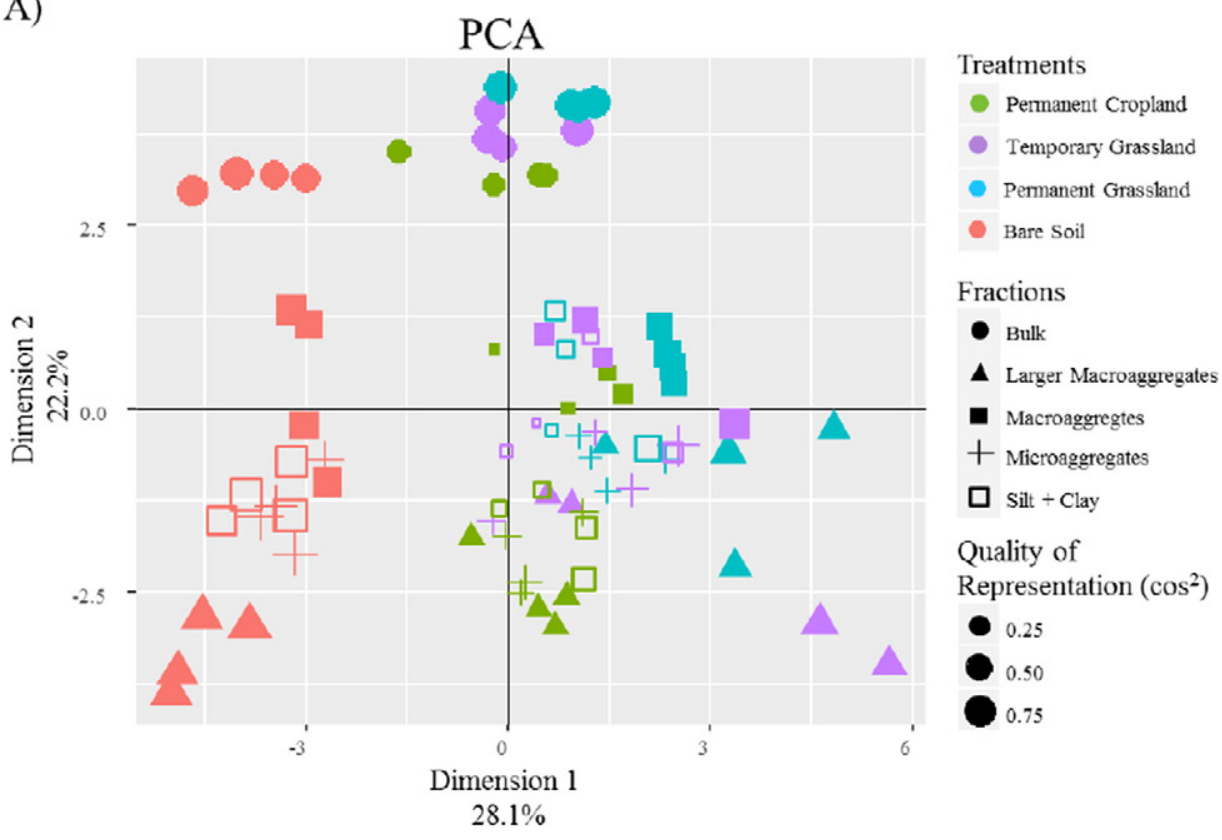

B)

3D-PCA

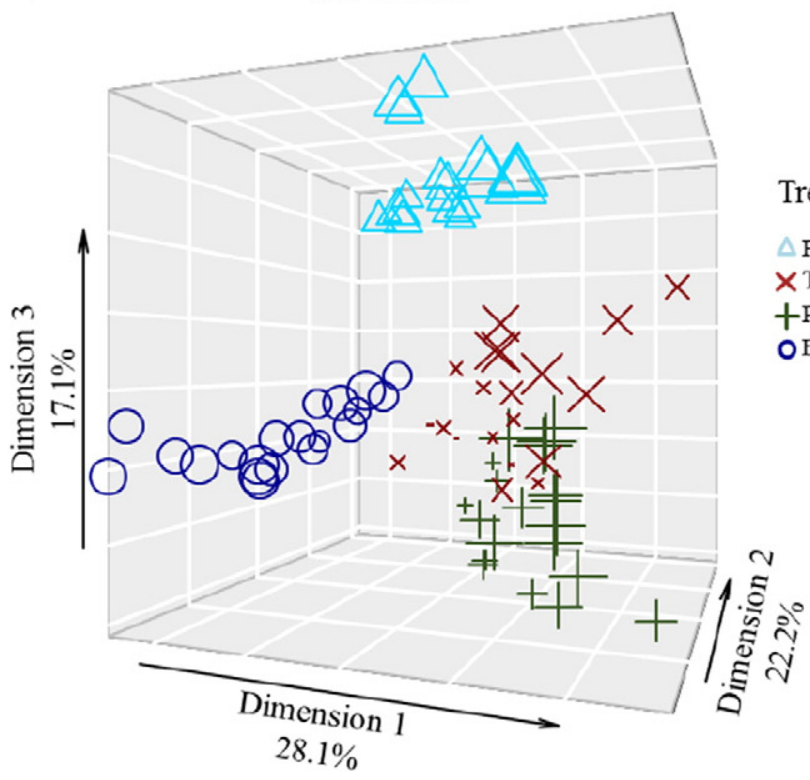

Fig. 5. Projected loadings of the soil parameters measured on aggregate-size fractions on the plain defined by the three first principal component.

fractions. In contrast, SOM of bare fallow soils showed similar values if compared to ley or permanent grassland soils only for the silt plus clay fraction $(\varnothing<0.050 \mathrm{~mm})$, in which SOM with supposed lower turnover rate due to stabilization by organo-mineral interactions is accumulated (Six et al., 2000b; Kögel-Knabner et al., 2008). Present results are in agreement with those by Tisdall and Oades (1982) and Puget et al. (2000) among others, identifying a gradient of SOM incorporation into water stable aggregates, with faster response to land-use change by larger aggregate fractions compared with silt plus clay ones. These findings were confirmed by the PCA analysis, in which larger macroaggregates from ley and permanent grassland were shifted on the right of the plot if compared with the same fraction of permanent cropland, whereas minor shifts were observed for finer fractions (Fig. 5A). The PCA plots unveiled how differences between treatments were more evident for the fractionated soil samples than for the bulk soil ones. Analyses on soil aggregates are likely to be more sensitive, even if significant differences in aggregate distribution were not found between the different treatments (Table 3). In contrast to these results, other studies reported aggregate disruption for permanent cropping and the opposite tendency was described for grassland (Tisdall and Oades, 1982; Six et al., 1998; Álvaro-Fuentes et al., 2008). This lack of effect of grassland conversion might be a result of the depth of sample collection, since higher aggregation strength is normally found at shallow layers for grasslands. Moreover, bare fallow plots (no litter inputs in the previous 9 years) did not show any significant difference in aggregate distribution either, compared with the other treatments, even if there was a tendency toward lower amounts of larger macroaggregates (ø 2-7.1 mm).

\subsection{SOM turnover within aggregates}

The turnover of SOM, expressed as $F$ values, for bulk soil samples were of similar magnitude as those reported in other studies with 
loamy agricultural soil under temperate climate (Balesdent et al., 1987; Dignac et al., 2005), but the present study highlighted huge variability in the rate of fresh SOM incorporation among different aggregate size fractions. These data showed that up to $25 \%$ of total SOM was composed by C4 plant residues in larger macroaggregates (ø 2-7.1 mm) after 9 years of continuous maize, while already $12.5 \%$ of SOM of the same fraction has been identified as $C 4$ derived after only 3 years of continuous maize. This may indicate that the rate of $\mathrm{C}$ incorporation into macroaggregates by new vegetation is not linear and may slow down with time. Moreover, the incorporation of new SOM followed a gradient decreasing with the size of aggregates, in agreement with previous studies by Puget et al. (2000). A slower turnover of SOM has been related with physico-chemical protection within the silt plus clay fraction and/or physical protection within microaggregates by other authors (Kögel-Knabner et al., 2008; Marschner et al., 2008).

Mean residence times (MRT) were calculated for the permanent cropland and for the temporary grassland plots after nine and three years of maize cultivation, respectively. Results highlighted different values between the two treatments only for the silt plus clay fraction $\emptyset<0.050 \mathrm{~mm}$, indicating smallest fractions as the most affected by the legacy of previous agronomical practices. A similar influence of landuse, and particularly tillage, on the smaller fractions of the soil was already found by two studies on carbon turnover in soils under permanent cropping evaluated by stable isotope analyses published by Balesdent et al. (1988, 1990).

\subsection{Lignin as a biomarker of land-use}

As for the TOC values, the fractionation process unveiled significant differences in the VSC lignin contents that were hidden for bulk samples (Fig. 2D). Larger macroaggregates (ø 2-7.1 mm) were once more responding rapidly to changing land-use: lignin phenols were significantly depleted in bare fallow plots as compared to other treatments. This could be explained by the mineralization of a lignin pool with a fast turnover allocated in larger macroaggregates (Dignac et al., 2005) or by a further degradation of lignin phenols into compounds not detected by the $\mathrm{CuO}$ oxidation method, such as demethylated phenols, as reported by other authors (Heim and Schmidt, 2007b; Hernes et al., 2013). For the same fraction, permanent grassland showed significantly higher contribution of VSC to TOC than permanently cropped soils, whereas three years of continuous maize produced a slight decrease of VSC in ley grassland, which showed no significant differences if compared with both permanent grassland and cropland. This lack of difference between soils under different land-uses is unexpected, as there were two times more lignin- $C_{\text {org }}$ returned every year through maize crops compared to grassland (Table 1). Since plant materials from maize roots and shoots showed considerably higher VSC to TOC ratios than grass roots, which contributed mostly to SOM of plots under grassland, the reason of such better lignin preservation under grassland are attributable to a higher quantity of lignin derived from decomposing root material, more resistant to degradation. In fact, VSC content was significantly correlated with root derived litter and root derived lignin, but not with inputs from shoots (Table 2). Contrasting results were obtained by Hofmann et al. (2009), who described lignin accumulation in soil proportional to maize litter amount and selective preservation of lignin against total SOM. Discrepancies between the two experiment can be explained by the different cropping conditions (field study $v s$. cylinders in absence of tillage) and by the missing information about belowground inputs in the experiment by Hofmann et al. (2009).

For bare fallow plots, an interaction of lignin phenols with the mineral matter was found, according to previous findings (Heim and Schmidt, 2007b). Lignin was depleted for all the fractions of bare fallow plots compared to the other treatments, except for the silt plus clay fraction $\varnothing<0.050 \mathrm{~mm}$. Kiem and Kögel-Knabner (2003) suggested a preferential preservation of lignin in silt fraction, which could be consistent also for our study, since silt and clay were not separated in our experiment. Hypotheses about this preservation are still not proved, nevertheless land-use factors as tillage and vegetal inputs should be taken into account to trace the persistence of lignin into the soil matrix. Indeed, VSC content in soils was positively correlated to root derived litter, but not with inputs from the shoots (Table 2), according to values obtained for TOC.

Further information about the degradation status of lignin phenols has been acquired comparing the ratios between the different monomeric units present in the soil and in the plant material, similarly to what was reported by Lobe et al. (2002). The lower amount of vanillyl units in the maize biomass is reflected by the higher $\mathrm{C} / \mathrm{V}$ and $\mathrm{S} / \mathrm{V}$ ratios found for the macroaggregates ( $\varnothing 2-7.1 \mathrm{~mm}$ ) of permanently cropped soils if compared with corresponding fractions of soil under permanent grassland. Three years of maize cultivation after ley grassland produced a significant increase of both ratios, suggesting a high incorporation of fresh lignin derived from maize litter in larger macroaggregates ( $\varnothing 2-$ $7.1 \mathrm{~mm}$ ), following the trends observed for C4 derived TOC values. Significant differences between cultivated plots were not found for other fractions, indicating that the steps of depolymerisation of more degradable lignin units (i.e. C and S) within slower turnover aggregate fractions could lead to a similar phenolic composition of the residual lignin (Heim and Schmidt, 2007a; Baumann et al., 2013).

The degradation pattern of the lignin involves the selective cleavage of the phenylpropanoid $\mathrm{C} \alpha-\mathrm{C} \beta$ bonds followed by the side-chains oxidation and the formation of carboxylic acid groups (Hedges et al., 1988). Due to the lack of fresh input, bare fallow plots stored lignin monophenols with the highest acid to aldehyde ratios, normally associated with more degraded soil lignin (Kögel-Knabner and Ziegler, 1993; Lobe et al., 2002; Bahri et al., 2006).

Despite maize roots and shoots had lower acid to aldehyde ratios, soil under permanent maize showed significantly higher Ac/Al-V ratios than ley grassland in larger macroaggregates (ø 2-7.1 mm), and higher Ac/Al-S ratio than permanent grassland for bulk soil. Similar tendencies were observed for the other fractions highlighting that the lignin inputs from maize crops are subject to faster oxidation than grass derived ones.

Pearson's correlations were obtained for each subset of data selected by treatment to unveil distinctive lignin degradation patterns for each treatment. Bare fallow samples showed that VSC was negatively correlated with $\mathrm{C} / \mathrm{V}$ and $\mathrm{Ac} / \mathrm{Al}-\mathrm{V}$ ratios $\left(\mathrm{R}^{2}-0.668\right.$ and -0.539 , respectively), indicating that in absence of fresh litter, preservation of lignin is enhanced by the presence of a higher proportion of $\mathrm{V}$ units in their aldehydic form. As reported by Kögel (1986), V units are less susceptible to degradation due to higher amount of aryl bonds formed which place these units in the central core of lignin structure.

For grassland samples, VSC was negatively correlated with Ac/Al-V and Ac/Al-S ratios $\left(\mathrm{R}^{2}-0.723\right.$ and -0.766 , respectively) confirming that degradation of lignin requires intermediate oxidation steps from aldehyde to acid in system with a constant input of fresh litter. Ley grassland samples showed correlations between VSC values and C/V and S/V ratios ( $R^{2} 0.574$ and 0.552 , respectively) not detected for permanent grassland samples. This result reflects the change in land-use and the incorporation of lignin inputs with higher contribution of $S$ and $C$ units derived from three years of continuous maize cropping.

\subsection{Ley grassland and long-term carbon storage}

Fertilization rates of the selected treatments are chosen to provide an adequate $\mathrm{N}$ supply to the system, as described in the material and methods section, thus we can assume that $\mathrm{N}$ is not a limiting factor for litter degradation in our experimental area (Lemaire et al., 2008). Even if the two different litter types have similar $C_{\text {org }}$ contents, grass roots were characterized by higher $\mathrm{N}$ contents, and grasslands were fertilized with higher amounts of $\mathrm{N}$, leading to higher soil TON content in larger macroaggregates (ø 2-7.1 mm) under permanent grassland as compared to permanent cropland. Furthermore, the stoichiometric factors controlling the quality of the litter, such as lower TOC/TON ratios, 
have been indicated by Smith et al. (2015b) as responsible of the negligible effects on soil aggregation after grassland conversion, as for plots under study. For the present experiment, TOC/TON ratios were negatively correlated $\left(R^{2}-0.419\right)$ with aggregate distribution and lower for grass roots than for maize ones. Moreover, grass litter was richer in $\mathrm{N}$ than maize litter (Table 2). Previous research described how $\mathrm{N}$ rich forest litter is decomposing faster at early stages, whereas $\mathrm{N}$ deposition could lower the litter decomposition rates through condensation of aromatic rings of lignin structure mediated by N (Berg and Matzner, 1997). Rasse et al. (2005) reported that root derived litter has higher lignin to $\mathrm{N}$ ratios shoot and leave derived ones, and the lower $\mathrm{N}$ content of the litter has been indicated as one of the factors for the preservation of lignin within the soil matrix. Nevertheless, maize litter had higher TOC/ TON and VSC/TON values than grass litter, indeed a lower degradation of litter would be expected (Sanaullah et al., 2010). However, TOC values were not different between treatments for bulk samples and VSC values were not increasing under maize for any of the analysed samples, despite the higher amount of lignin returned to soil by maize crops.

The SOM dynamics after the conversion to grassland could be explained by: (I) a larger belowground biomass input for grass species, correlated with TOC and lignin contents, which could be immediately subject to organo-mineral interactions (Rasse et al., 2005) and thus maximize the stabilization and protection of SOM, and (II) the absence of tillage in plots under grassland, which provokes a stratification of SOM and decreased degradation due to a lower aeration and redistribution of fresh litter to deeper layers (Lal, 1997; Franzluebbers, 2004; Lemaire et al., 2015).

To summarize our findings, the introduction of grassland into crop rotations did not produce significant increases of TOC and lignin for bulk samples at a 0-30 cm depth, but one complete cycle of ley grassland increased TOC and lignin contents in the fast responding aggregate fractions, identified as those of larger size (ø 0.200-2 mm and ø 2$7.1 \mathrm{~mm}$ ). Indeed, taking into account the lignin balance of litter returned to soil and VSC values, a more efficient lignin preservation was detected for plots under either ley or permanent grassland, as compared to continuous maize cropping. Since tillage is responsible of fungal hyphae disruption, a lower degradation of lignin by with rot fungi under cropland is expected (Thevenot et al., 2010). Other factors such as $\mathrm{N}$ availability, litter composition, and other lignin decomposition patterns may be responsible of this result, and are actually under study on the same experimental area. For ley grassland samples, the footprint obtained during 6 years of grassland was still dominant after three years of continuous maize, as demonstrated by the three-dimensional PCA analysis.

This short term storage is counterbalanced by the longer MRT detected for $\mathrm{C}_{\text {org }}$ in finer fractions of ley grassland soil, if compared with continuous maize ones. These results suggested that the higher root density and the absence of tillage were responsible of a tight interaction of litter derived $\mathrm{C}_{\text {org }}$ with finer fraction of the soil. This interaction resulted in a "positive" legacy effect generated by ley grassland, which could increase the storage at longer term. It should be remarked that the experimental area has been devoted to continuous cropping for decades, and a "negative" legacy effect hampering soil recovery has to be expected after a conversion to permanent or ley grassland (Compton et al., 1998). Longer periods of time are often required to appreciate net carbon storage in similar ecosystems (Smith, 2014). These findings indicated the possibility of a net carbon storage in ley grassland plots at long-term, maintaining adequate economic benefits for landholder as compared to continuous cropping (Glover et al., 2010; Lemaire et al., 2014). Further research is needed, since more cycles of grassland/ cropland alternation are necessary to overtake the inertia of the system and to monitor the reverse legacy effect induced by grassland on the persistence of SOM in those agroecosystems.

Since SOM is mainly composed of root derived material (Rasse et al., 2005), superficial root systems as those described in this experiment, may need longer time to show a significant storage of SOM, whereas grass species with deep roots have been described as more efficient even at short term (Lemaire et al., 2014; Richter et al., 2015). Moreover, the quality of litter, the stoichiometric limitations, and the effect of tillage practices are often neglected factors of carbon storage research (Bruun et al., 2015), but data presented in this study strongly suggest including them in the overall evaluation of $\mathrm{C}_{\text {org }}$ storage in agroecosystem.

\section{Conclusion}

Differences in aggregate distribution between grassland and cropland were not found for surface soil corresponding to the arable layer, but the composition of the aggregate fractions changed strongly under different treatments. The hierarchic approach, which combined separation of water-stable aggregates and analyses of specific biomarkers allowed unveiling some dynamics, which were hidden for bulk soil. The inclusion of maize derived lignin and SOM was detected after three years of maize cultivation for ley grassland, but the grassland footprint was still dominating the nature of SOM in ley grassland samples as revealed by PCA analysis.

The increase of carbon stocks for larger fractions, identified as a short term effect, was combined with an increase in $\mathrm{C}_{\text {org }}$ mean residence time for the silt plus clay fraction under ley grassland. This result suggests a possible allocation for a "positive legacy" effect induced by the six years of ley grassland in the rotation, which could result in a longterm storage of $\mathrm{C}_{\text {org }}$ in these soils.

Possible explanations for these results are: (I) an enhanced degradation of the litter driven by the tillage, and (II) more abundant organomineral interactions preserving SOM from degradation and driven by the higher root density under grassland. Lignin balance showed that lignin stocks were more efficiently preserved under ley and permanent grassland than under permanently cropped soils.

This study highlighted the needs of an overall evaluation of the parameters modified by land-use changes, (i.e. stoichiometry, quality and quantity of the vegetal inputs returned to soil, tillage practices) to achieve more accurate prediction for long-term SOM storage. Further understanding on the role of plant inputs on aggregate formation and protection may be improved by the analysis of the isotopic composition of lignin and other biomarkers, which allows to understand the turnover rate of specific compound classes within the soil matrix.

\section{Acknowledgments}

The authors acknowledge funding from ADEME under the framework of the AEGES project. This publication has been written with the support of the AgreenSkills fellowship programme which has received funding from the EU Seventh Framework Programme under grant agreement no. FP7-26719. Financial support by the Transnational Access to Research Infrastructures activity in the 7th Framework Programme of the EC under the ExpeER project no. 262060 for conducting the research is gratefully acknowledged by the authors.

The authors would like to thank X. Charrier for his technical support at the experimental area SOERE-ACBB (Systems of Observation and Experimentation in Environmental Research-Agro-ecosystem, Biogeochemical Cycles and Biodiversity http://www.soere-acbb.com/fr/), V. Pouteau, C.Girardin, and D. Billiou for their technical support in the analyses carried out, and A. Crème and J. Barthod for the support in statistical analysis.

\section{References}

Abiven, S., Menasseri, S., Chenu, C., 2009. The effects of organic inputs over time on soil aggregate stability - a literature analysis. Soil Biol. Biochem. 41, 1-12.

Álvaro-Fuentes, J., Arrúe, J.L., Gracia, R., López, M.V., 2008. Tillage and cropping intensification effects on soil aggregation: temporal dynamics and controlling factors under semiarid conditions. Geoderma 145, 390-396.

Armas-Herrera, C.M., Dignac, M.F., Rumpel, C., Arbelo, C.D., Chabbi, A., 2016. Management effects on composition and dynamics of cutin and suberin in topsoil under agricultural use. Eur. J. Soil Sci. 67, 360-373 (n/a-n/a). 
Bahri, H., Dignac, M.F., Rumpel, C., Rasse, D.P., Chenu, C., Mariotti, A., 2006. Lignin turnover kinetics in an agricultural soil is monomer specific. Soil Biol. Biochem. 38, 1977-1988.

Balesdent, J., Mariotti, A., 1996. Measurement of soil organic matter turnover using ${ }^{13} \mathrm{C}$ natural abundance. In: Boutton, T.W., Yamasaki, S.I. (Eds.), Mass Spectrometry of Soils. Marcel Dekker, New York (USA), pp. 83-111.

Balesdent, J., Mariotti, A., Guillet, B., 1987. Natural ${ }^{13} \mathrm{C}$ abundance as a tracer for studies of soil organic matter dynamics. Soil Biol. Biochem. 19, 25-30.

Balesdent, J., Wagner, G.H., Mariotti, A., 1988. Soil organic matter turnover in long-term field experiments as revealed by carbon-13 natural abundance. Soil Sci. Soc. Am. J. $52,118-124$.

Balesdent, J., Mariotti, A., Boisgontier, D., 1990. Effect of tillage on soil organic carbon mineralization estimated from ${ }^{13} \mathrm{C}$ abundance in maize fields. J. Soil Sci. 41, 587-596.

Baumann, K., Sanaullah, M., Chabbi, A., Dignac, M.F., Bardoux, G., Steffens, M., KögelKnabner, I., Rumpel, C., 2013. Changes in litter chemistry and soil lignin signature during decomposition and stabilisation of ${ }^{13} \mathrm{C}$ labelled wheat roots in three subsoil horizons. Soil Biol. Biochem. 67, 55-61.

Berg, B., Matzner, E., 1997. Effect of $\mathrm{N}$ deposition on decomposition of plant litter and soil organic matter in forest systems. Environ. Rev. 5, 1-25.

Bronick, C.J., Lal, R., 2005. Soil structure and management: a review. Geoderma 124, 3-22.

Bruun, T.B., Elberling, B., de Neergaard, A., Magid, J., 2015. Organic carbon dynamics in different soil types after conversion of forest to agriculture. Land Degrad. Dev. 26 (3), 272-283.

Chabbi, A., Kögel-Knabner, I., Rumpel, C., 2009. Stabilised carbon in subsoil horizons is located in spatially distinct parts of the soil profile. Soil Biol. Biochem. 41, 256-261.

Clemente, J.S., Simpson, M.J., 2013. Physical protection of lignin by organic matter and clay minerals from chemical oxidation. Org. Geochem. 58, 1-12.

Compton, J.E., Boone, R.D., Motzkin, G., Foster, D.R., 1998. Soil carbon and nitrogen in a pine-oak sand plain in central Massachusetts: role of vegetation and land-use history. Oecologia 116, 536-542.

Derenne, S., Nguyen Tu, T.T., 2014. Characterizing the molecular structure of organic matter from natural environments: an analytical challenge. Compt. Rendus Geosci. 346, 53-63.

Dignac, M.F., Bahri, H., Rumpel, C., Rasse, D.P., Bardoux, G., Balesdent, J., Girardin, C., Chenu, C., Mariotti, A., 2005. Carbon-13 natural abundance as a tool to study the dynamics of lignin monomers in soil: an appraisal at the Closeaux experimental field (France). Geoderma 128, 3-17.

Elliott, E.T., 1986. Aggregate structure and carbon, nitrogen, and phosphorus in native and cultivated soils1. Soil Sci. Soc. Am. J. 50, 627-633.

Franzluebbers, A.J., 2002. Soil organic matter stratification ratio as an indicator of soil quality. Soil Tillage Res. 66, 95-106.

Franzluebbers, A.J., 2004. Tillage and residue management effects on soil organic matter. In: Magdoff, F., Weil, R.R. (Eds.), Soil Organic Matter in Sustainable Agriculture. CRC Press, Boca Raton, pp. 227-268.

Gelfand, I., Sahajpal, R., Zhang, X., Izaurralde, R.C., Gross, K.L., Robertson, G.P., 2013. Sustainable bioenergy production from marginal lands in the US Midwest. Nature 493, 514-517.

Girardin, C., Mariotti, A., 1991. Isotopic analysis of ${ }^{13} \mathrm{C}$ natural abundance in organic carbon: an automated system with robotised preparer. Cahiers - ORSTOM, Serie Pedologie 26, 371-380.

Gleixner, G., Poirier, N., Bol, R., Balesdent, J., 2002. Molecular dynamics of organic matter in a cultivated soil. Org. Geochem. 33, 357-366.

Glover, J.D., Culman, S.W., DuPont, S.T., Broussard, W., Young, L., Mangan, M.E., Mai, J.G., Crews, T.E., DeHaan, L.R., Buckley, D.H., Ferris, H., Turner, R.E., Reynolds, H.L., Wyse, D.L., 2010. Harvested perennial grasslands provide ecological benchmarks for agricultural sustainability. Agric. Ecosyst. Environ. 137, 3-12.

Hedges, J.I., Ertel, J.R., 1982. Characterization of lignin by gas capillary chromatography of cupric oxide oxidation products. Anal. Chem. 54, 174-178.

Hedges, J.I., Blanchette, R.A., Weliky, K., Devol, A.H., 1988. Effects of fungal degradation on the $\mathrm{CuO}$ oxidation products of lignin: a controlled laboratory study. Geochim. Cosmochim. Acta 52, 2717-2726.

Heim, A., Schmidt, M.W.I., 2007a. Lignin turnover in arable soil and grassland analysed with two different labelling approaches. Eur. J. Soil Sci. 58, 599-608.

Heim, A., Schmidt, M.W.I., 2007b. Lignin is preserved in the fine silt fraction of an arable Luvisol. Org. Geochem. 38, 2001-2011.

Hernes, P.J., Kaiser, K., Dyda, R.Y., Cerli, C., 2013. Molecular trickery in soil organic matter: hidden lignin. Environ. Sci. Technol. 47, 9077-9085.

Hofmann, A., Heim, A., Christensen, B.T., Miltner, A., Gehre, M., Schmidt, M.W.I., 2009. Lignin dynamics in two ${ }^{13} \mathrm{C}$-labelled arable soils during 18 years. Eur. J. Soil Sci. 60, 250-257.

Hu, G., Liu, H., Yin, Y., Song, Z., 2016. The role of legumes in plant community succession of degraded grasslands in northern China. Land Degrad. Dev. 27 (2), 366-372.

IPCC, 2013. Climate change 2013: the physical science basis. Contribution of Working Group I to the Fifth Assessment Report of the Intergovernmental Panel on Climate Change. Cambridge University Press, Cambridge, United Kingdom and New York, NY, USA.

Jackson, R.B., Canadell, J., Ehleringer, J.R., Mooney, H.A., Sala, O.E., Schulze, E.D., 1996. A global analysis of root distributions for terrestrial biomes. Oecologia 108, 389-411.

Keesstra, S.D., Bouma, J., Wallinga, J., Tittonell, P., Smith, P., Cerdà, A., Montanarella, L., Quinton, J.N., Pachepsky, Y., van der Putten, W.H., Bardgett, R.D., Moolenaar, S., Mol, G., Jansen, B., Fresco, L.O., 2016. The significance of soils and soil science towards realization of the United Nations Sustainable Development Goals. Soil 2, 111-128.

Kiem, R., Kögel-Knabner, I., 2003. Contribution of lignin and polysaccharides to the refractory carbon pool in C-depleted arable soils. Soil Biol. Biochem. 35, 101-118.

Kögel, I., 1986. Estimation and decomposition pattern of the lignin component in forest humus layers. Soil Biol. Biochem. 18, 589-594.
Kögel, I., Bochter, R., 1985. Characterization of lignin in forest humus layers by high-performance liquid chromatography of cupric oxide oxidation products. Soil Biol. Biochem. 17, 637-640.

Kögel-Knabner, I., Ziegler, F., 1993. Carbon distribution in different compartments of forest soils. Geoderma 56, 515-525.

Kögel-Knabner, I., Ekschmitt, K., Flessa, H., Guggenberger, G., Matzner, E., Marschner, B., Von Lützow, M., 2008. An integrative approach of organic matter stabilization in temperate soils: linking chemistry, physics, and biology. J. Plant Nutr. Soil Sci. $171,5-13$.

Kunrath, T.R., de Berranger, C., Charrier, X., Gastal, F., de Faccio Carvalho, P.C., Lemaire, G. Emile, J.C., Durand, J.L., 2015. How much do sod-based rotations reduce nitrate leaching in a cereal cropping system? Agric. Water Manag. 150, 46-56.

Lal, R., 1997. Residue management, conservation tillage and soil restoration for mitigating greenhouse effect by $\mathrm{CO}_{2}$-enrichment. Soil Tillage Res. 43, 81-107.

Lal, R., 2000. Soil conservation and restoration to sequester carbon and mitigate the greenhouse effect. In: Rubio, J.L., Asins, S., Andreu, V., de Paz, J.M., Gimeno, E. (Eds.), Key Notes, 3rd International Congress European Society for Soil Conservation: Man and Soil at the Third Millennium, pp. 5-20 (Valencia).

Lal, R., 2002. Soil conservation and restoration to sequester carbon and mitigate the greenhouse effect. European Society for Soil Conservation, Third International Congress. Key notes, Man and Soil at the Third Millennium, pp. 5-20.

Le Bissonnais, Y., 1996. Aggregate stability and assessment of soil crustability and erodibility: I. Theory and methodology - Stabilité structurale et évaluation de la sensibilité des sols à la battance et à l'érosion: I: Théorie et méthologie. Eur. J. Soil Sci. 47 425-437.

Leifeld, J., Kögel-Knabner, I., 2005. Soil organic matter fractions as early indicators for carbon stock changes under different land-use? Geoderma 124, 143-155.

Lemaire, G., Jeuffroy, M.H., Gastal, F., 2008. Diagnosis tool for plant and crop N status in vegetative stage. Theory and practices for crop N management. Eur. J. Agron. 28, 614-624.

Lemaire, G., Hodgson, J., Chabbi, A., 2011. Grassland Productivity and Ecosystems Services.

Lemaire, G., Franzluebbers, A., Carvalho, P.C.D.F., Dedieu, B., 2014. Integrated crop-livestock systems: strategies to achieve synergy between agricultural production and environmental quality. Agric. Ecosyst. Environ. 190, 4-8.

Lemaire, G., Gastal, F., Franzluebbers, A., Chabbi, A., 2015. Grassland-cropping rotations an avenue for agricultural diversification to reconcile high production with environmental quality. Environ. Manag. 56, 1065-1077.

Lobe, I., Du Preez, C.C., Amelung, W., 2002. Influence of prolonged arable cropping on lignin compounds in sandy soils of the South African Highveld. Eur. J. Soil Sci. 53, 553-562.

Ludwig, M., Achtenhagen, J., Miltner, A., Eckhardt, K.-U., Leinweber, P., Emmerling, C., Thiele-Bruhn, S., 2015. Microbial contribution to SOM quantity and quality in density fractions of temperate arable soils. Soil Biol. Biochem. 81, 311-322.

Marschner, B., Brodowski, S., Dreves, A., Gleixner, G., Gude, A., Grootes, P.M., Hamer, U. Heim, A., Jandl, G., Ji, R., Kaiser, K., Kalbitz, K., Kramer, C., Leinweber, P., Rethemeyer, J., Schäffer, A., Schmidt, M.W.I., Schwark, L., Wiesenberg, G.L.B., 2008. How relevant is recalcitrance for the stabilization of organic matter in soils? J. Plant Nutr. Soil Sci. 171, 91-110.

Moni, C., Rumpel, C., Virto, I., Chabbi, A., Chenu, C., 2010. Relative importance of sorption versus aggregation for organic matter storage in subsoil horizons of two contrasting soils. Eur. J. Soil Sci. 61, 958-969.

Panettieri, M., Knicker, H., Berns, A.E., Murillo, J.M., Madejón, E., 2013. Moldboard plowing effects on soil aggregation and soil organic matter quality assessed by ${ }^{13} \mathrm{C}$ CPMAS NMR and biochemical analyses. Agric. Ecosyst. Environ. 177, 48-57.

Panettieri, M., Berns, A.E., Knicker, H., Murillo, J.M., Madejón, E., 2015. Evaluation of seasonal variability of soil biogeochemical properties in aggregate-size fractioned soi under different tillages. Soil Tillage Res. 151, 39-49.

Parras-Alcántara, L., Díaz-Jaimes, L., Lozano-García, B., 2015. Management effects on soil organic carbon stock in Mediterranean open rangelands-treeless grasslands. Land Degrad. Dev. 26 (1), 22-34.

Puget, P., Chenu, C., Balesdent, J., 2000. Dynamics of soil organic matter associated with particle-size fractions of water-stable aggregates. Eur. J. Soil Sci. 51, 595-605.

Rasse, D.P., Rumpel, C., Dignac, M.F., 2005. Is soil carbon mostly root carbon? Mechanisms for a specific stabilisation. Plant Soil 269, 341-356.

Rasse, D.P., Dignac, M.F., Bahri, H., Rumpel, C., Mariotti, A., Chenu, C., 2006. Lignin turnover in an agricultural field: from plant residues to soil-protected fractions. Eur. J. Soil Sci. 57, 530-538.

Richter, G.M., Agostini, F., Redmile-Gordon, M., White, R., Goulding, K.W.T., 2015. Sequestration of $C$ in soils under Miscanthus can be marginal and is affected by genotypespecific root distribution. Agric. Ecosyst. Environ. 200, 169-177.

Rumpel, C., Baumann, K., Remusat, L., Dignac, M.F., Barré, P., Deldicque, D., Glasser, G., Lieberwirth, I., Chabbi, A., 2015. Nanoscale evidence of contrasted processes for root-derived organic matter stabilization by mineral interactions depending on soil depth. Soil Biol. Biochem. 85, 82-88.

Sanaullah, M., Chabbi, A., Lemaire, G., Charrier, X., Rumpel, C., 2010. How does plant leaf senescence of grassland species influence decomposition kinetics and litter compounds dynamics? Nutr. Cycl. Agroecosyst. 88, 159-171.

Senapati, N., Chabbi, A., Gastal, F., Smith, P., Mascher, N., Loubet, B., Cellier, P., Naisse, C. 2014. Net carbon storage measured in a mowed and grazed temperate sown grassland shows potential for carbon sequestration under grazed system. Carbon Manage. 5, 131-144.

Six, J., Paustian, K., 2014. Aggregate-associated soil organic matter as an ecosystem property and a measurement tool. Soil Biol. Biochem. 68, A4-A9.

Six, J., Elliott, E.T., Paustian, K., Doran, J.W., 1998. Aggregation and soil organic matter accumulation in cultivated and native grassland soils. Soil Sci. Soc. Am. J. 62, 1367-1377. 
Six, J., Elliott, E.T., Paustian, K., 1999. Aggregate and soil organic matter dynamics under conventional and no-tillage systems. Soil Sci. Soc. Am. J. 63, 1350-1358.

Six, J., Elliott, E.T., Paustian, K., 2000a. Soil macroaggregate turnover and microaggregate formation: a mechanism for $\mathrm{C}$ sequestration under no-tillage agriculture. Soil Biol. Biochem. 32, 2099-2103.

Six, J., Elliott, E.T., Paustian, K., 2000b. Soil structure and soil organic matter: II. A normalized stability index and the effect of mineralogy. Soil Sci. Soc. Am. J. 64, 1042-1049.

Smith, P., 2014. Do grasslands act as a perpetual sink for carbon? Glob. Chang. Biol. 20, 2708-2711.

Smith, P., Cotrufo, M.F., Rumpel, C., Paustian, K., Kuikman, P.J., Elliott, J.A., McDowell, R., Griffiths, R.I., Asakawa, S., Bustamante, M., House, J.I., Sobocká, J., Harper, R., Pan, G. West, P.C., Gerber, J.S., Clark, J.M., Adhya, T., Scholes, R.J., Scholes, M.C., 2015a. Biogeochemical cycles and biodiversity as key drivers of ecosystem services provided by soils. Soil 1, 665-685.
Smith, R., Tongway, D., Tighe, M., Reid, N., 2015b. When does organic carbon induce aggregate stability in vertosols? Agric. Ecosyst. Environ. 201, 92-100.

Studdert, G.A., Echeverría, H.E., Casanovas, E.M., 1997. Crop-pasture rotation for sustaining the quality and productivity of a Typic Argiudoll. Soil Sci. Soc. Am. J. 61, 1466.

Thevenot, M., Dignac, M.F., Rumpel, C., 2010. Fate of lignins in soils: a review. Soil Biol. Biochem. 42, 1200-1211.

Thevenot, M., Dignac, M.F., Mendez-Millan, M., Bahri, H., Hatté, C., Bardoux, G., Rumpel, C., 2013. Ligno-aliphatic complexes in soils revealed by an isolation procedure: implication for lignin fate. Biol. Fertil. Soils 49, 517-526.

Tisdall, J.M., Oades, J.M., 1982. Organic matter and water-stable aggregates in soils. J. Soil Sci. 33, 141-163. 